\title{
Seeded pioneer die-offs reduce the functional trait space of new-growth coastal
}

dune forests

Victor Rolo ${ }^{1 *}$, Pieter Olivier ${ }^{1}$ and Rudolph van Aarde ${ }^{1}$

${ }^{1}$ Conservation Ecology Research Unit, University of Pretoria, Hatfield, 0028, Pretoria, South Africa

*Corresponding author: victorroloromero@gmail.com

Running head: Traits, environment and vegetation dynamics 


\section{Abstract}

The planting or seeding of pioneer species to promote restoration apparently contributes little to the establishment of late-successional species, despite the common assumption that they facilitate forest regeneration. We evaluate the consequences of planting pioneers for coastal dune restoration by measuring plant traits (specific leaf area, wood density, $\delta^{13} \mathrm{C}$ and maximum plant height), species composition and canopy openness in three rehabilitating forests of different ages, where a pioneer species (Acacia karroo) was seeded, and one undisturbed old-growth forest. We surveyed woody species composition in 2010 and in 2015 to assess how changes in A. karroo influences community structure of rehabilitating forest. Our results showed that the number of adult individuals of $A$. karroo decreased progressively with forest age, indicating that the demise of individuals of A. karroo opens canopy gaps in rehabilitating sites. This accorded with a significantly higher variation of canopy openness levels in the oldest rehabilitating site. Rehabilitating sites tended to progress towards a reduced trait space as they aged, contrasting with the old-growth forest that showed an expanded trait space. Communities located at high levels of canopy openness were dominated by species with lower values of specific leaf area and wood density, indicative of acclimation to high light conditions and fast-growing strategies. Our results suggest that changes in light availability due to canopy gap formation, can act as an environmental filter which may deflect forest regeneration trajectories. We show that coupling a trait-based approach with environmental measurements can give insight in regeneration trajectories of rehabilitating sites and, therefore, better inform restoration practices. Preventing the formation of large canopy gaps in restoration programs using pioneers as a regeneration pathway may facilitate the natural recovery of degraded forest. 
Keywords: Functional diversity, forest restoration, canopy gaps, environmental filtering, hemispherical photographs, community assembly

\section{Introduction}

The planting or seeding of fast-growing species (i.e. pioneers) is commonly used to initiate and promote ecological restoration (Chazdon, 2008; Cusack and Montagnini, 2004; Lamb et al., 2005). Support for this practice comes from natural forests where shade-tolerant guilds (i.e. late-successional) replace pioneers following a disturbance event (Chazdon, 2011; Dent et al., 2013; Lebrija-Trejos et al., 2010a). However, the reliance on the establishment of pioneers to restore vegetation through succession needs further investigation (Boyes et al., 2011; McNamara et al., 2006; Podadera et al., 2015; Vleut et al., 2013). Contrary to popular belief pioneers may not facilitate forest regeneration, but simply tolerate or even inhibit the colonization of late-successional species (Connell and Slatyer, 1977).

Pioneer species have high growth and mortality rates (Russo et al., 2008; Wright et al., 2010). Their high growth rates accords with a facilitating role, because it can promote a quick increase of tree cover during early successional stages, promote the establishment of shade-tolerant species, and inhibit self-replacement (Dent et al., 2013; Lebrija-Trejos et al., 2010a). On the other hand, the high mortality rates of pioneers may inhibit the establishment of late-successional species (Vleut et al., 2013). For instance, simultaneous die-offs of pioneers could open large canopy gaps, which can facilitate their selfreplacement and hinder the establishment of late-successional species (Bazzaz, 1979; Whitmore, 1989). Thus, seeding pioneers may jeopardize restoration by inhibiting secondary species from colonizing regenerating forests. However, how the demise of 
planted pioneers influences regenerating pathways in rehabilitating forest has rarely been assessed.

The functional traits of plants have been used to evaluate and plan restoration programs (Asanok et al., 2013; Laughlin, 2014; Nguyen et al., 2014). Conceptually, the regeneration of forests should progress from a functionally narrow subset of species with similar trait values during the early stages of succession (i.e. trait convergence), towards an increasingly wide functional trait space at late successional stages (i.e. trait divergence) (Buzzard et al., 2015; Lasky et al., 2014b; Lohbeck et al., 2014). More generally, this interpretation can be accommodated into a filter model framework to explain successional processes (Meiners et al., 2015). Of all the potential colonizers from the regional species pool, environmental conditions will only select for those species with traits that promote establishment and persistence (i.e. environmental filters). Afterwards, competition and/or other determinants of performance will reorganize species (Meiners et al., 2015). In this way, if the demise of pioneers promotes an abrupt change in environmental conditions, it may remove species with traits that cannot cope with the altered conditions (i.e. shadetolerant) and deflects the regeneration trajectory away from the targeted vegetation 'endpoint' (Mouillot et al., 2013). Assessing how the functional trait space varies in a regenerating, new-growth forest that uses pioneers may therefore provide information about the processes structuring the community (e.g. environmental filters).

However, addressing only how the functional trait space change over time may not fully unravel the drivers that control vegetation dynamics. For instance, studies that failed to find deterministic changes in functional structure during succession may have overlooked the strong relationship between plant traits and their environment (Lebrija-Trejos et al., 
2010b). Indeed, in systems where human-induced disturbances have strongly altered community composition, trait-environment relationships have responded deterministically (Amatangelo et al., 2014). If the environment plays an important role in shaping community structure, the inclusion of environmental factors relevant to the studied systems, together with functional structure, may provide more insight into the mechanisms that drive forest development (Lebrija-Trejos et al., 2010b). By assessing linkages between functional traits and environmental variables, restoration efforts can be better informed. In addition, by understanding how biotic and abiotic factors are linked in studies of forest development, responses to disturbance and subsequent community assembly can be compared among different sites (Meiners et al., 2015).

In this study, we combine functional trait indices with canopy openness measurements to assess the role of seeded pioneers, and identify a possible mechanism that could drive forest development in rehabilitating coastal dune forest in KwaZulu-Natal, South Africa. Here, the pioneer species, Acacia karroo was seeded after sand tailings were reshaped into dunes (van Aarde et al., 1996). Previous studies within these forests have shown how tree species composition changes following the senescence of $A$. karroo (Grainger and van Aarde, 2013). However, it is uncertain if canopy gaps that are formed through the senescence of the pioneer species promote an increased functional trait space as expected in a successional context (Lohbeck et al., 2014), or promotes a set of species with similar trait values (i.e. environmental filters). We specifically aim to answer: What are the implications of the demise of A. karroo on regenerating trajectories of rehabilitating coastal dune forest? We hypothesize that the formation of canopy gaps will act as an environmental filter and lead to the establishment of species with a narrow set of traits (i.e. fast growing, acclimated to high light conditions) deflecting the regeneration 
trajectory away from the reference site. Overall, we expect that coupling functional traits with light availability will help to better inform restoration programs that uses pioneers as a regenerating pathway.

\section{Material and Methods}

\subsection{Study area}

Our study sites were located within a set of rehabilitating forests on mined coastal sand dunes and within an undisturbed, old-growth coastal dune forest (Sokhulu forest, $28^{\circ} 27^{\prime} \mathrm{S}$, $32^{\circ} 25^{\prime}$ E; hereafter old-growth) in KwaZulu-Natal, South Africa (Fig.1). The studied forests were located approximately $60 \mathrm{~km}$ north of Richards Bay $\left(28^{\circ} 43^{\prime} \mathrm{S}, 32^{\circ} 12^{\prime} \mathrm{E}\right)$ and formed part of the Indian Ocean Coastal Belt (IOCB) forests of southern Africa (Mucina and Rutherford, 2006). The IOCB covers a narrow strip (less than $\sim 35 \mathrm{~km}$ wide) along $800 \mathrm{~km}$ of the eastern seaboard of South Africa and represents the southernmost range of East African Coastal Forest that extends northwards as far as southern Somalia (Burgess and Clarke, 2000). The climate of the study area is humid and sub-tropical (van Aarde et al., 2014). Long-term mean annual rainfall since rehabilitation (1976-2015) was $1336 \pm$ $117 \mathrm{~mm}$ year $^{-1}$ (see Fig. A1 for further details).

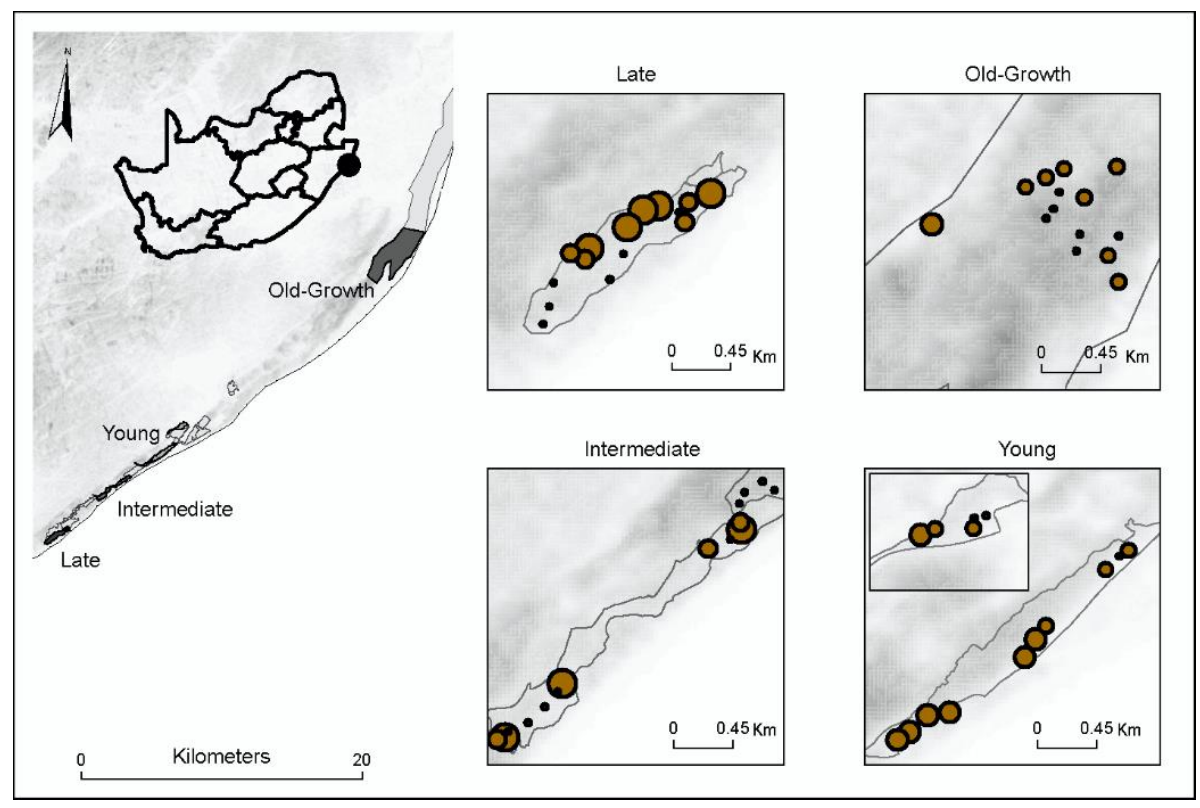


Fig.1 Overview of the study area and sampling sites. Sampling points are depicted by circles, of which the size is proportional to canopy openness levels.

The unmined old-growth forest included in this study was situated about $20 \mathrm{~km}$ northeast of the rehabilitating sites. This forest was $\sim 500$ ha in size and part of the dune forest in the Mapelane Nature Reserve ( 1500 ha), which forms part of the iSimangaliso Wetland Park. This old-growth forest was the closest relatively large patch of undisturbed forest to the mining lease area. Rehabilitating sites and the old-growth forest had similar abiotic conditions (Fig. A2).

The mining process started in 1976 and required the removal of all vegetation and topsoil ahead of the dredge pond (van Aarde et al., 1996). After mining the sand tailings were reshaped into dunes and covered with the pre-mined harvested topsoil. Forest species seeds have minimal dormancy (Fenner and Thompson, 2005), and it is unlikely that viable seeds were retained in the topsoil. These sites were seeded with a cover crop of annuals and grasses enriched with the seeds of A. karroo, and afterwards the vegetation was allowed to develop on its own accord (van Aarde et al., 1996). This resulted in the establishment of a sequence of known-aged sites. Acacia karroo is a pioneer tree species that can naturally occur in coastal dune forest (Boyes et al 2011). Individuals of A. karroo have been shown to be senescent by about 20 years old (Gourlay et al., 1996). After this age, dead individuals fell and start to leave gaps in the canopy (Grainger and van Aarde, 2013). Our study sites therefore comprise a set of new-growth forests that are regenerating in response to rehabilitation measures to restore coastal dune forests through succession.

2.2 Sampling scheme and data collection 
Four sites (three new-growth forest sites and an old-growth forest) were sampled in 2010 and 2015. The age of new-growth forest sites was 18, 26 and 33 years in 2010 (hereafter: young, intermediate, and late, respectively). This age represents the number of years since rehabilitation started. Aerial photographs of the old-growth forest show that this forest patch has been intact before 1937 (Wassenaar et al., 2005). At each site, 15 quadrats of $16 \times 16 \mathrm{~m}$ were placed at random locations in 2010 and re-sampled in 2015 . We sampled $\sim 0.4$ ha per site, while the total area of sites ranged between 50 and 70 ha. Sampling points in rehabilitating sites and in the old-growth forest had a similar abiotic environment in terms of aspect, slope and elevation (Fig. A2). In each survey, all woody individuals higher than $0.2 \mathrm{~m}$ were identified at the species level and counted. The height of the canopy, defined as the height of the tallest trees that occupy at least $5 \%$ of the canopy (West, 2009), was measured per quadrat with a range finder (Nikon Laser 550As; Nikon, Tokyo, Japan). Additionally, the diameter at breast height (DBH) was measured in all woody individuals higher than $1.7 \mathrm{~m}$. Individuals with a $\mathrm{DBH}<1 \mathrm{~cm}$ were classified as seedlings and the others as adults. The category defined as adult combined saplings and adults in the same group. Saplings and adults are usually distinguished in two size classes based on a common threshold irrespective of the woody species type. However, we opted to categorize individual trees in this way because different woody species types (shrubs, mid-canopy trees and canopy trees) were present in our study sites. The proper distinction between both size classes per woody species type would therefore require detailed knowledge on species-specific growth rates and age, which is beyond the scope of this study.

We quantified canopy openness (sensu Jennings et al. 1999) by taking five hemispherical photographs at three different exposure settings in each quadrat. We used a Canon 6D 
camera (Canon Inc. Tokyo, Japan) mounted on a 1m tripod (Benro, KB1, USA) and fitted with a Canon 8-14mm fish eye lens (Canon Inc. Tokyo, Japan). Hemispherical photographs were taken following Pfeifer et al. (2012). Canopy openness (\%) was calculated for each hemispherical photograph by means of Gap Light Analyzer (GLA) software (Frazer et al., 1999) and averaged for each quadrat.

\subsection{Functional traits}

We measured functional traits on species that collectively represented $>99 \%$ of the individuals at each site (Table A1). Only individuals with enough DBH to measure wood density (see below) were selected. One individual per species was randomly selected per quadrat to quantify the functional structure of the sampled community. This ensured that intraspecific trait variability, that can have an important effect on the functional structure of a community, was taken into account in our sampling (Carmona et al., 2014). We determined four functional traits in each selected individual (specific leaf area, $\delta^{13} \mathrm{C}$, wood density and maximum plant height). These traits reflect different ecological strategies of plants (Westoby et al., 2002; Wright et al., 2010) and are sensitive to community assembly processes (Buzzard et al., 2015; Lohbeck et al., 2014). We followed standardized protocols to measure functional traits (Cornelissen et al., 2003; PérezHarguindeguy et al., 2013). For leaf traits, we collected sun-exposed leaves, when possible, from the mid-to-upper part of the canopy. Leaves were scanned with a flatbed scanner (CanonScan LiDE 220). Leaf area was calculated from these images using ImageJ software (Schneider et al., 2012). Specific leaf area (SLA, $\left.\mathrm{cm}^{2} / \mathrm{g}\right)$, calculated as the fresh leaf area per oven-dried mass, is part of the leaf economic spectrum and relates to the plant's ability to acquire and use nutrients (Wright et al., 2004). Low specific leaf area values indicates a conservative strategy with low relative growth rates (Westoby et 
al., 2002). Oven-dry leaves were ground to fine powder using a grinding mill and stable carbon isotope composition (express as delta notation $(\delta)$ and per mille (\%)) was analyzed in a stable isotope ratio mass spectrometer (Thermoquest EA 1110 elemental analyser). $\delta^{13} \mathrm{C}$ describes the ratio of ${ }^{13} \mathrm{C}$ to ${ }^{12} \mathrm{C}$ within foliar tissue has been shown to increase with light availability (Letts et al., 2012) and is positively related to water use efficiency, that increases with evaporative demand (Dawson et al. 2002). However, other factors such as rooting depth, soil moisture or nitrogen availability can also affect $\delta^{13} \mathrm{C}$ values (Dawson et al. 2002). Wood density (WD, g / cc) was measured using wood cores, extracted with a $5.15 \mathrm{~mm}$ core diameter increment borer (Haglöf, Sweden) on individuals of DBH > 5 $\mathrm{cm}$. Wood density was computed as oven-dried mass divided by the fresh volume that was calculated using the water displacement method. Wood density is part of the stem economic spectrum and co-varies with other hydraulic traits. High values of wood density indicates low growth rates, high stress tolerance to shade, wind, drought and herbivores (Chave et al., 2009; Wright et al., 2010). Maximum plant height (PH, m) was compiled from bibliographic sources (Germishuizen et al., 2003). Maximum plant height is related to resource availability, especially light, and competitive environments, with high plant height competitive advantages through prior access to light (Westoby et al., 2002). However, in our study plant height represents the potential position of each species in the vertical light gradient of the vegetation.

\subsection{Data analysis}

To quantify differences in forest structure between sites per year, we used linear mixed models that included sampling quadrat as a random factor. We included site and year as independent variables and stem density (number of individuals per quadrat), species density (number of species per quadrat, sensu Chazdon, 2011) and basal area (BA, m² ha 
${ }^{1}$ ) as dependent variables. As canopy height (m) and canopy openness (\%) were only measured in 2015, we used a one-way ANOVA to test for differences between sites. We distinguish between $A$. karroo and other species in all our analyses. We used Kolmogorov-Smirnov tests to assess if the distribution of individuals of A. karroo and other species differed between 2010 and 2015.

For each trait we calculated community-level weighted mean values (CWM) to describe the dominant trait value per quadrat. This metric was calculated as:

$$
C W M=\sum_{i=1}^{n} p_{i} \text { trait }_{i}
$$

where $\mathrm{p}_{\mathrm{i}}$ and trait $\mathrm{i}_{\mathrm{i}}$ are the relative abundance and the trait value for species $\mathrm{i}$, respectively, and $\mathrm{n}$ is the total number of species. This index estimates the most probable attribute that a species drawn at random from a community would display (Swenson, 2014). We used linear mixed-effects models that included quadrat as a random effect to assess the differences in CWM. Additionally, we computed functional dispersion values (FD, Laliberté and Legendre, 2010) considering all traits together (multivariate FD) and individually (univariate FD) to describe how the species are distributed in the trait space. This metric is the mean distance in multi-dimensional space of individual species to the centroid of all species present and, therefore, describes if a community shows convergent or divergent trait values. We used a null model approach to test the effect of site on multivariate FD values. Null models allow the comparison of observed communities with randomly assembled communities of equal species richness (Gotelli and Graves, 1996). To generate the random communities, a matrix describing the abundance of each species was randomly permuted (999 times) per site and year keeping species richness per quadrat constant. For each randomization, functional dispersion was calculated. We used a 
standardized effect size (SES) to compare the deviation of observed values relative to the null model assemblage. SES is calculated as the ratio of the difference between the observed value and the mean of the null distribution, divided by the standard deviation (SD) of the null distribution:

$$
\mathrm{SES}=\frac{(\text { Observed-Null) }}{\mathrm{SD}(\text { Null })}
$$

The null hypothesis is that the average SES is zero. Thus, an SES value that is significantly lower than zero indicates a lower than average expected value in a random community (trait value convergence, i.e. environmental filtering). To assess if SES values deviates from zero, we computed $95 \%$ CIs per site, size class and year. We considered that SES values were significantly different from zero when their $95 \%$ CIs did not include it.

To compute all functional diversity indices, mean trait values of each species were calculated per site. This strategy has been shown to accurately describe changes in functional structure along ecology gradients while taking into account intraspecific trait variability (Carmona et al 2014). For species with missing trait values in a particular site (because it was not big enough to be cored or only appeared as a seedling), we assigned the mean value of that species from the rest of sites. Seedling species were assigned adult trait values using the same procedure. We are aware that assigning adult traits values to seedlings could limit the assessment of the functional structure of the seedling community, but given the differences in species composition between size classes in coastal forest (Lawes et al., 2004), and that interspecific variation of traits can be consistent across ontogeny (Iida et al. 2014), we expect a limited effect of assigning adult trait values to seedlings (Lasky et al., 2015). We included A. karroo abundance and trait values in the seedling stage to calculate CWM and FD indices, but not in the adult stage to avoid the confounding effect of being seeded. 
To assess the relationship between canopy openness and patterns of SES FD, CWM and univariate FD, we used linear mixed models that included site as a random factor. These models only included data from 2015, when canopy openness was measured. We included size class (adult and seedlings), canopy openness and their interaction as predictors. We calculated the variance explained by both fixed and random factors (conditional $\mathrm{R}^{2}$ ) of the models following Nakagawa and Schielzeth (2013). All analyses were carried out in the $\mathrm{R}$ statistical environment (v3.1.1, R Development Core Team 2013) using the packages lme4 (Bates, 2010) and FD (Laliberté and Legendre, 2010).

\section{Results}

\subsection{Forest structure}

Forest structural variables were significantly different in the old-growth forest than in rehabilitating sites (Table 1). Canopy heights were significantly lower in the old-growth forest than in rehabilitating sites. The old-growth forest showed the highest values of species density, followed by the late site. Similarly, the old-growth forest had higher values of stem density and BA than rehabilitating sites, where these values tend to increase with forest age.

In the rehabilitating sites, $A$. karroo stem density and BA values tended to decrease as the forest aged with lower values in the late than in young and intermediate sites (Table 1). This result was in accordance with the significantly different distributions of A. karroo individuals in 2010 and 2015 across sites (Fig. 2), indicating a progressive reduction in the number of $A$. karroo individuals as the forest aged. The coefficient of variation of canopy openness was significantly higher in the late, than in the young and intermediate sites, indicating a more heterogeneous environment (Table 1). However, average values of canopy openness did not differ among young, intermediate and late rehabilitating sites 
Table 1 Mean value of forest structure variables: stem density (number of individuals per quadrat), species density (number of species per quadrat), basal area (BA, m $\mathrm{ha}^{-1}$ ), canopy height $(\mathrm{m})$, canopy openness $(\%)$ and the coefficient of variation $(\mathrm{CV})$ of canopy openness in rehabilitating sites and an old-growth forest measured in 2010 and 2015. Note the distinction between other species and A. karroo for stem density and BA values in rehabilitating sites. Different letters depict significant differences at $\mathrm{P}<0.05$ among sites per year.

\begin{tabular}{|c|c|c|c|c|c|c|}
\hline & & Year & Young & Intermediate & Late & Old-Growth \\
\hline \multirow{4}{*}{ Stem density } & \multirow{2}{*}{ Other sp. } & 2010 & $11.87 \pm 0.98 \mathrm{a}$ & $12.93 \pm 2.68 \mathrm{a}$ & $23.8 \pm 3.85 \mathrm{a}$ & $53 \pm 5.54 b$ \\
\hline & & 2015 & $24 \pm 2.87 \mathrm{ab}$ & $12.67 \pm 1.91 \mathrm{a}$ & $39.6 \pm 5.01 \mathrm{~b}$ & $64.47 \pm 7.83 c$ \\
\hline & \multirow{2}{*}{ A. karroo } & 2010 & $30.33 \pm 2.73 \mathrm{c}$ & $15.2 \pm 1.3 \mathrm{~b}$ & $5.13 \pm 0.96 \mathrm{a}$ & - \\
\hline & & 2015 & $18.4 \pm 1.38 \mathrm{~b}$ & $10.27 \pm 1.34 \mathrm{a}$ & $4.93 \pm 1.51 \mathrm{a}$ & - \\
\hline \multirow{4}{*}{ BA } & \multirow{2}{*}{ Other sp. } & 2010 & $0.29 \pm 0.06 \mathrm{a}$ & $0.58 \pm 0.13 \mathrm{a}$ & $2.29 \pm 0.51 b$ & $28.38 \pm 4.04 \mathrm{c}$ \\
\hline & & 2015 & $0.70 \pm 0.14 \mathrm{a}$ & $1.0 \pm 0.23 \mathrm{a}$ & $4.62 \pm 0.90 \mathrm{~b}$ & $31.43 \pm 3.32 \mathrm{c}$ \\
\hline & \multirow{2}{*}{ A. karroo } & 2010 & $17.24 \pm 1.01 \mathrm{~b}$ & $17.31 \pm 0.82 \mathrm{~b}$ & $6.72 \pm 1.34 \mathrm{a}$ & - \\
\hline & & 2015 & $15.96 \pm 0.89 b$ & $15.67 \pm 1.08 \mathrm{~b}$ & $4.82 \pm 1.16 \mathrm{a}$ & - \\
\hline \multirow{2}{*}{\multicolumn{2}{|c|}{ Species density }} & 2010 & $7.87 \pm 0.7 \mathrm{ab}$ & $5.73 \pm 0.68 \mathrm{a}$ & $10.47 \pm 1.12 b$ & $20.4 \pm 1.01 \mathrm{c}$ \\
\hline & & 2015 & $11.33 \pm 1.39 \mathrm{a}$ & $7.47 \pm 0.93 \mathrm{a}$ & $15.8 \pm 1.36$ & $24.27 \pm 1.16 \mathrm{c}$ \\
\hline \multicolumn{2}{|c|}{ Canopy height } & 2015 & $15.74 \pm 1.01 \mathrm{~b}$ & $15.86 \pm 0.96 b$ & $12.42 \pm 1.86 \mathrm{ab}$ & $10.50 \pm 0.83 a$ \\
\hline \multicolumn{2}{|c|}{ Canopy openness } & 2015 & $27.60 \pm 2.60 \mathrm{ab}$ & $33.33 \pm 1.91 \mathrm{~b}$ & $30.13 \pm 4.14 b$ & $19.96 \pm 2.24 \mathrm{a}$ \\
\hline \multicolumn{2}{|c|}{ CV Canopy openness } & 2015 & $0.24 \pm 0.03 \mathrm{a}$ & $0.21 \pm 0.03 \mathrm{a}$ & $0.45 \pm 0.05 b$ & $0.32 \pm 0.03 \mathrm{a}$ \\
\hline
\end{tabular}

\subsection{Patterns of functional diversity}

The deviation of functional dispersion patterns from the random expectation (i.e. $95 \%$ CIs intervals did not include zero) depended on the site and size class considered (Fig. 3). For adults, we observed a reduction in the trait space in the oldest rehabilitating site, indicative of trait convergence. The intermediate site did not differ from the random expectation. However, the youngest site showed positive SES values in 2015, indicative of trait divergence. The old-growth forest showed positive SES values during both years (Fig. 3) (i.e. trait divergence). Patterns of CWM accorded with these results, having the communities of the oldest rehabilitating site significant lower values of specific leaf area, while the youngest site of wood density and plant height (Table 2). 

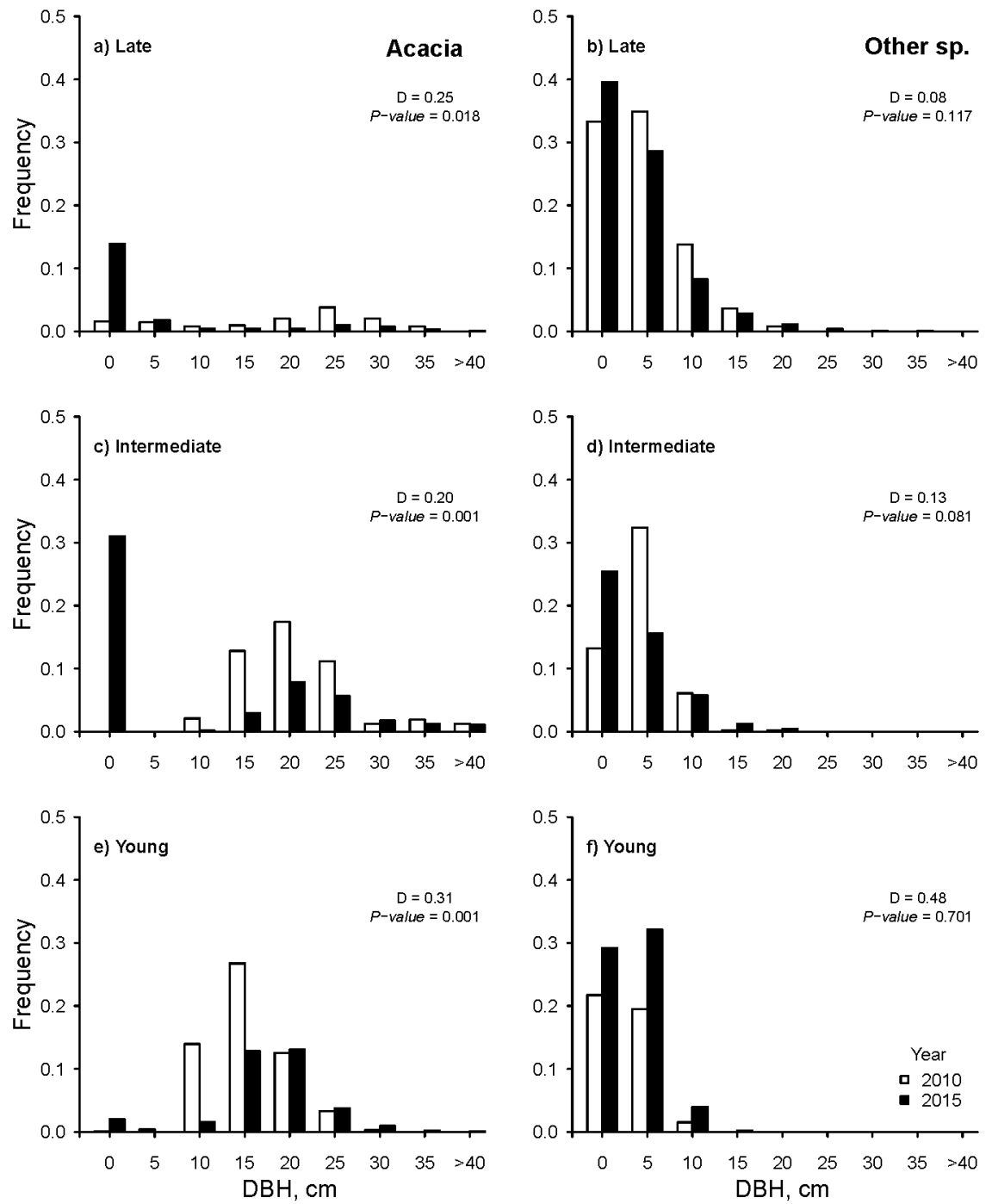

Figure 2. Frequency distributions of individuals (A. karroo and other species) based on their DBH in rehabilitating sites in 2010 and 2015. Note that the category of zero DBH represents the seedling size class. We did not include the old-growth forest for simplicity. It showed an inverse J-Shape distribution, typical of mature forest, both years.

For seedlings, patterns of SES values were less evident than for the adult size class (Fig. 3). Younger rehabilitating sites did not deviate from the random expectation, whereas the late rehabilitating site and the old-growth forest tend to show negative and positive SES values, respectively. Similarly, seedling patterns of CWM were less consistent than those 
for adults, showing only the oldest rehabilitating site significantly lower values of specific leaf area.
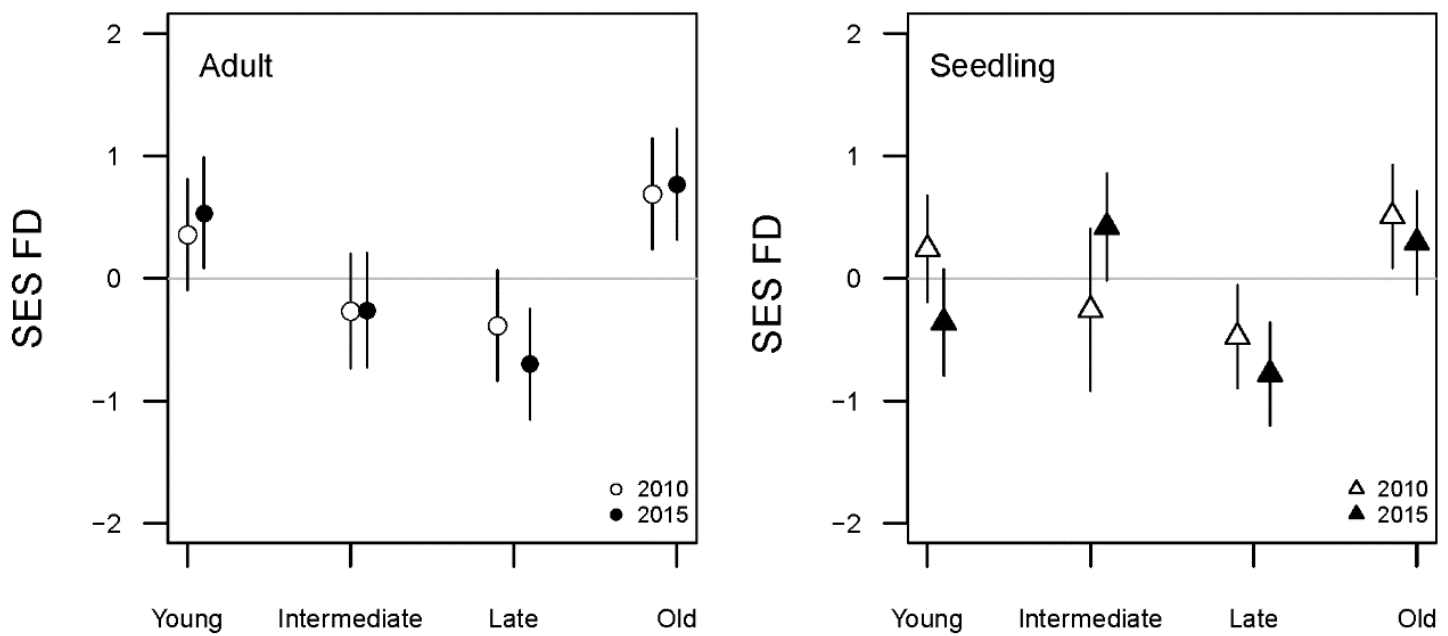

Figure 3: Standardize effect size values of multivariate functional dispersion of adults and seedlings measured in 2010 and 2015 in rehabilitating stands and an old-growth forest. SES values significantly lower than zero indicates a lower than average expected value in a random community (trait value convergence, i.e. environmental filtering), while SES values significantly higher than zero indicates trait value divergence.

Table 2. Community weight means values $\left( \pm 95 \%\right.$ CIs) of specific leaf area (SLA, $\mathrm{cm}^{2} \mathrm{~g}^{-}$ ${ }^{1}$ ), wood specific gravity (WSG g cc $\left.{ }^{-1}\right)$, carbon stable isotopic composition $\left(\delta^{13} \mathrm{C} \%\right.$ ) and maximum plant height $(\mathrm{PH}, \mathrm{m})$ of adults and juveniles communities measured in 2010 and 2015 in rehabilitating stands and an old-growth forest. Different letters depict significant differences at $\mathrm{P}<0.05$ among sites per year.

\begin{tabular}{|c|c|c|c|c|c|}
\hline & & Young & Intermediate & Late & Old-Growth \\
\hline Adults & Year & & & & \\
\hline \multirow[t]{2}{*}{ SLA } & 2010 & $159.17 \pm 9.1 b$ & $150.31 \pm 4.17 b$ & $126.4 \pm 2.97 \mathrm{a}$ & $165.72 \pm 4.66 b$ \\
\hline & 2015 & $174.34 \pm 8.87 \mathrm{c}$ & $151.21 \pm 4.37 \mathrm{~b}$ & $125.85 \pm 2.22 \mathrm{a}$ & $162.83 \pm 4.07 \mathrm{bc}$ \\
\hline \multirow[t]{2}{*}{ WSG } & 2010 & $0.642 \pm 0.005 \mathrm{c}$ & $0.596 \pm 0.007 \mathrm{a}$ & $0.618 \pm 0.005 \mathrm{ab}$ & $0.629 \pm 0.008 b c$ \\
\hline & 2015 & $0.641 \pm 0.004 b$ & $0.592 \pm 0.007 \mathrm{a}$ & $0.625 \pm 0.003 \mathrm{~b}$ & $0.629 \pm 0.007 b$ \\
\hline$\delta^{13} \mathrm{C}$ & 2010 & $-29.82 \pm 0.17 \mathrm{a}$ & $-29.54 \pm 0.13 \mathrm{a}$ & $-30.40 \pm 0.08 b$ & $-30.69 \pm 0.05 b$ \\
\hline
\end{tabular}




\begin{tabular}{cccccc} 
& 2015 & $-30.07 \pm 0.12 \mathrm{~b}$ & $-29.60 \pm 0.13 \mathrm{a}$ & $-30.42 \pm 0.06 \mathrm{bc}$ & $-30.68 \pm 0.04 \mathrm{c}$ \\
PH & 2010 & $14.01 \pm 0.97 \mathrm{~b}$ & $13.52 \pm 1.03 \mathrm{~b}$ & $12.57 \pm 0.56 \mathrm{ab}$ & $10.14 \pm 0.49 \mathrm{a}$ \\
& 2015 & $14.21 \pm 1.05 \mathrm{~b}$ & $12.36 \pm 1.11 \mathrm{a}$ & $11.70 \pm 0.55 \mathrm{a}$ & $10.68 \pm 0.38 \mathrm{a}$ \\
Seedlings & & & & & \\
SLA & 2010 & $149.82 \pm 8.26 \mathrm{~b}$ & $140.94 \pm 8.14 \mathrm{~b}$ & $132.46 \pm 3.98 \mathrm{a}$ & $158.68 \pm 3.76 \mathrm{~b}$ \\
& 2015 & $167.1 \pm 9.74 \mathrm{~b}$ & $150.25 \pm 1.96 \mathrm{ab}$ & $141.07 \pm 3.41 \mathrm{a}$ & $162.8 \pm 4.29 \mathrm{ab}$ \\
WSG & 2010 & $0.639 \pm 0.01 \mathrm{~b}$ & $0.596 \pm 0.014 \mathrm{a}$ & $0.631 \pm 0.004 \mathrm{~b}$ & $0.611 \pm 0.005 \mathrm{ab}$ \\
& 2015 & $0.648 \pm 0.007 \mathrm{~b}$ & $0.638 \pm 0.006 \mathrm{ab}$ & $0.647 \pm 0.004 \mathrm{~b}$ & $0.614 \pm 0.008 \mathrm{a}$ \\
$\delta^{13} \mathrm{C}$ & 2010 & $-29.73 \pm 0.28 \mathrm{a}$ & $-30.07 \pm 0.34 \mathrm{ab}$ & $-30.79 \pm 0.12 \mathrm{c}$ & $-30.77 \pm 0.09 \mathrm{bc}$ \\
& 2015 & $-30.45 \pm 0.11$ & $-30.26 \pm 0.09$ & $-30.92 \pm 0.05$ & $-30.67 \pm 0.08$ \\
PH & 2010 & $11.75 \pm 0.85 \mathrm{~b}$ & $8.37 \pm 1.14 \mathrm{ab}$ & $11.39 \pm 0.94 \mathrm{ab}$ & $7.66 \pm 0.33 \mathrm{a}$ \\
& 2015 & $11.50 \pm 1.10 \mathrm{ab}$ & $15.1 \pm 1.45 \mathrm{~b}$ & $12.61 \pm 0.98 \mathrm{~b}$ & $8.63 \pm 0.49 \mathrm{a}$ \\
\hline
\end{tabular}

3.3 Relationship between canopy openness and functional diversity

The relationship between canopy openness and functional diversity indices depended on the size class considered. Standardized effect size values of multivariate FD were only negatively related to canopy openness for adults (significant interaction between canopy openness and size class, $\left.P=0.008, \mathrm{R}^{2}=0.20\right)$. Similarly, when considering each trait individually, we found significant relationships between canopy openness and functional dispersion (FD) and CWM trait values, although these depended on the size class considered (Fig. 4). Only CWM values of $\delta^{13} \mathrm{C}$ and FD values of specific leaf area showed a similar response among size classes (no significant interaction between canopy openness and size class). Adults showed a negative relationship between CWM values of specific leaf area and wood density and canopy openness, whereas seedlings showed a positive relationship with plant height CWM values. Functional dispersion values of specific leaf area and plant height were negatively related to canopy openness for adult plants. For seedlings, we observed a negative relationship between canopy openness and FD values of wood density and $\delta^{13} \mathrm{C}$. 

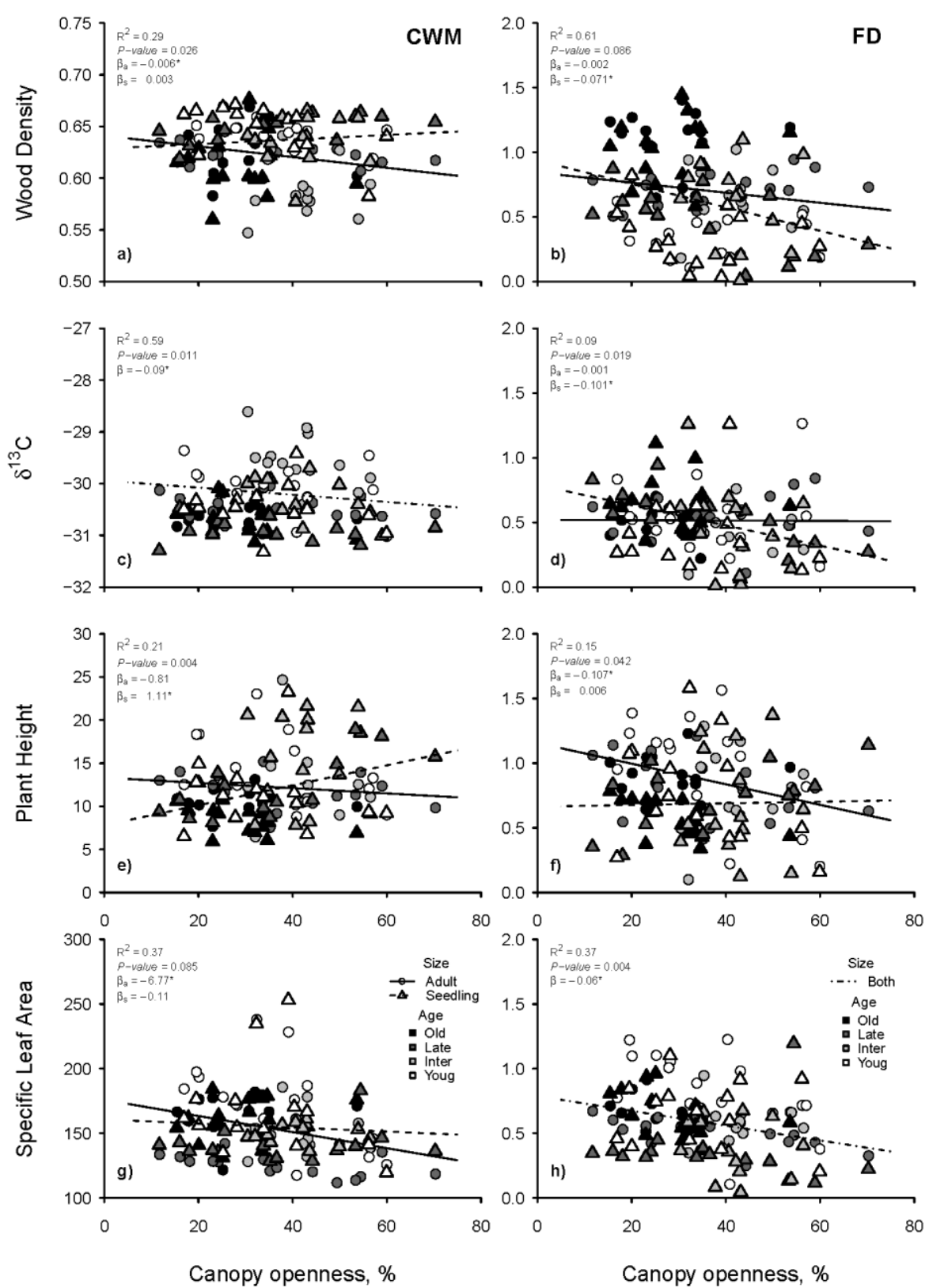

Figure 4: Relationship between community weighted mean (CWM) and functional dispersion (FD) values of specific leaf area $\left(\mathrm{cm}^{2} \mathrm{~g}^{-1}\right)$, wood density $\left(\mathrm{g} \mathrm{cc}^{-1}\right)$, carbon isotopic composition $\left(\delta^{13} \mathrm{C}, \%\right.$ o $)$ and plant height $(\mathrm{m})$ of adults and seedlings in rehabilitating stands and an old-growth forest. $P$-values indicates either the interaction between size class (adults of seedlings) and canopy openness or only the main effect of canopy openness when the interaction was not significant (both). Asterisks indicates a significant slope of adults $(\beta a)$, seedlings $(\beta s)$, or both $(\beta)$. 


\section{Discussion}

Many ecological restoration programs rely on the planting or seeding of pioneers to initiate and promote vegetation recovery. Our results partially support this practice, showing an apparent recovery of forest structural variables and an increase in species density in new-growth forests over time. However, the seeding of pioneers may have a limited effect on the recovery of functional diversity levels. Since succession drives coastal dune forest regeneration (Grainger and Aarde, 2012; Rolo et al., 2016), functional diversity should change with regeneration age towards a divergent trait space (Lohbeck et al., 2014). However, trait space was more divergent in old-growth than new-growth forests where trait space became less divergent as the forest aged. Although factors not considered in this study (e.g. legacy effects or site configuration) may explain this finding, our results suggest that changes in light conditions associated with the demise of pioneers, drive patterns of functional diversity in new-growth forests away from those in old growth forests.

\subsection{Environmental filtering and the functional structure of rehabilitating forest}

High disturbance regimes can remove species with traits that are poorly adapted to the altered conditions and allow colonization by better adapted species (Mouillot et al., 2013). This agrees with the notion of environmental filtering. However, environmental filtering is usually observed at early successional stages. Indeed, in a successional context, a shift from a reduced (convergent) towards an increased (divergent) trait space is expected as the forest ages (Lohbeck et al., 2014). However, we found the opposite; the functional trait space was narrower in the oldest than in the youngest rehabilitating site. This was particularly evident for adult trees, and contrasts with the divergent trait space found in the old-growth forest. This result suggests that the new light conditions promotes the 
persistence of a different set of species than in the old-growth forest. For seedlings, the deviation of functional trait space from the random expectation was less marked than for adults, possibly because different ecological processes may structure each size class (Spasojevic et al., 2014). Given that dispersal limitation influence tree species assemblages in coastal forests (Olivier and van Aarde, 2014), the lack of a clear departure from the random expectation in the seedling size class may result from a combined effect of dispersal limitation from the species pool and the presence of canopy gaps.

\subsection{Functional traits and canopy openness}

The negative relationship between CWM and FD values and light availability for adult trees reinforce the notion that canopy gaps allow for the presence of a different set of species in the new-growth forests than in the old-growth forest. For instance, at high levels of light availability, adult species showed low CWM values of wood density. This suggests that larger canopy gaps are dominated by fast-growing species (Wright et al., 2010). Species with a fast-growing strategy should show high values of specific leaf area (Poorter and Bongers, 2006), but we observed the opposite. Nevertheless, it has been suggested that stem and leaf traits are not coordinated (Baraloto et al., 2010), indicating that the lower values of SLA may represent a phenotypic acclimation to high levels of light availability (Poorter, 2001). Additionally, each functional trait can reveal different mechanisms that drive forest regeneration (Lasky et al., 2014a). In the seedling size class, the positive relationship between CWM values of plant height and light availability may represent the substantial increase of A. karroo abundance between time steps (Fig. 2). Acacia karroo was the third highest plant $(22 \mathrm{~m})$ in our study sites where tree height ranged between 3 to $30 \mathrm{~m}$. The likely increase in A. karroo abundance between time steps 
may have important consequences for the restoration program, because it reveals a risk of self-replacing of $A$. karroo.

\subsection{Seeded pioneers, canopy gaps and regenerating trajectories}

Our results suggest that restoration efforts where pioneer species are seeded or planted can lead to synchronized die-offs and the development of large gaps in canopies that allows for changes in light conditions. It seems that when $A$. karroo individuals reach a DBH of about $20 \mathrm{~cm}$, they start to be senescent at a rate of about $0.3 \mathrm{~m}^{2} \mathrm{ha}^{-1} \mathrm{year}^{-1}$. Indeed, we observed that the reduction in the number of individuals of $A$. karroo between surveys took place mostly at intermediate $\mathrm{DBH}$ values (Fig. 2). Although there were no differences in mean values of light levels among rehabilitating sites, we observed that the mode clearly increased as the site aged $(20.5 \%, 26.3,37.8,61.2$, in old-growth, young, intermediate and late sites respectively). A similar increase in the coefficient of variation support the notion of a constant decay of A. karroo and the opening of canopy gaps when they die. These results suggest that the decay of $A$. karroo does not lead to an intermediate disturbance regime; rather it likely leads to the development of 'novel' conditions that can potentially compel a different dynamic in the rehabilitating sites than in the oldgrowth forest.

\subsection{Management implications}

Several management strategies, such as monoculture- and mixed-plantings, applied nucleation, enrichment seeding or passive restoration among others, are commonly used to rehabilitate degraded ecosystems in tropical and sub-tropical regions (e.g. Holl and Aide, 2011; Lamb, 2014; Rodrigues et al., 2009). The selection of the appropriate strategy depends on several factors, ranging from the objective of the restoration project, the 
funding available and the ecological properties of the system to be restored, such as past land-use history, surrounding landscape matrix and natural ecosystem resilience (Holl and Aide, 2011). However, despite applying the optimal strategy, it is important to adopt an evidence-based approach to properly inform and guide recovery of degraded systems (Suding, 2011). Here we demonstrate that coupling a trait-based approach with environmental measurements, relevant for the studied system, can give insights in the ecological processes operating in the new-growth forests and help to inform the restoration strategies. Using this approach, we showed that synchronized die-offs of $A$. karroo create new light conditions that allowed the establishment of a different set of species than in the old-growth forest. Previous studies in these sites has shown a linear increase in species richness and trait space of reproductive traits as the forest aged (Rolo et al., 2016), which suggests that minimizing the formation of large canopy gaps could revert the pattern observed in this study. Overall, the divergent trait space of adult individuals in the youngest rehabilitating site suggests that management interventions may stop the convergence of functional traits. The age of this stand was around 23 years old, a similar age than when A. karroo has been describe to be senescent (Gourlay, Smith \& Barnes, 1996). Thus, to promote functionally similar patterns than in the undisturbed old-growth forests, the creation of large gaps should be avoided by actively managing forest structure. For example, using selective thinning, before the pioneer species start to be senescent, or adjusting the density of $A$. karroo seeds in the restoration program may reduce the creation of large canopy gaps and limit their effects on the functional composition of the understory. Given the observed partial recovery of structural variables, the lack of convergence in species composition to the original vegetation does not necessarily mean a restoration failure. However, a certain adaptive capacity and resilience must be guaranteed in the rehabilitating system (Hobbs et al., 2009), which is more likely 
to be achieved if the rehabilitating forest has an expanded functional structure (Isbell et al., 2011).

\section{Acknowledgements}

We thank Richards Bay Minerals for supporting and facilitating and funding our fieldwork. We are indebted to Glenda Varrie, many research assistants, graduate and postgraduate students who participated in fieldwork over the years. RJvA was supported by the National Research Foundation (NRF) and the Technology and Human Resources for Industry Programme (THRIP). V. Rolo and P. Olivier were supported by a post-doctoral grant from the NRF of South Africa.

\section{References}

Amatangelo, K.L., Johnson, S.E., Rogers, D.A., Waller, D.M., 2014. Trait-environment relationships remain strong despite 50 years of trait compositional change in temperate forests. Ecology 95, 1780-1791. doi:10.1890/13-0757.1

Asanok, L., Marod, D., Duengkae, P., Pranmongkol, U., Kurokawa, H., Aiba, M., Katabuchi, M., Nakashizuka, T., 2013. Relationships between functional traits and the ability of forest tree species to reestablish in secondary forest and enrichment plantations in the uplands of northern Thailand. For. Ecol. Manag. 296, 9-23. doi:10.1016/j.foreco.2013.01.029

Baraloto, C., Marcon, E., Morneau, F., Pavoine, S., Roggy, J.-C., 2010. Integrating functional diversity into tropical forest plantation designs to study ecosystem processes. Ann. For. Sci. 67, 303. doi:10.1051/forest/2009110

Bates, D., 2010. Ime4: Mixed-effects modeling with R. Springer, Heidelberg, Germany. 
Bazzaz, F., 1979. The physiological ecology of plant succession. Annu. Rev. Ecol. Syst. $10,351-371$.

Boyes, L.J., Gunton, R.M., Griffiths, M.E., Lawes, M.J., 2011. Causes of arrested succession in coastal dune forest. Plant Ecol. 212, 21-32. doi:10.1007/s11258010-9798-6

Burgess, N.D., Clarke, G.P., 2000. Coastal Forests of Eastern Africa. IUCN The World Conservation Union.

Buzzard, V., Hulshof, C.M., Birt, T., Violle, C., Enquist, B.J., 2015. Re-Growing a tropical dry forest: functional plant trait composition and community assembly during succession. Funct. Ecol. doi:10.1111/1365-2435.12579

Carmona, C.P., Rota, C., Azcárate, F.M., Peco, B., 2014. More for less: sampling strategies of plant functional traits across local environmental gradients. Funct. Ecol. n/a-n/a. doi:10.1111/1365-2435.12366

Chave, J., Coomes, D., Jansen, S., Lewis, S.L., Swenson, N.G., Zanne, A.E., 2009. Towards a worldwide wood economics spectrum. Ecol. Lett. 12, 351-366. doi:10.1111/j.1461-0248.2009.01285.x

Chazdon, R., 2011. Chance and determinism in tropical forest succession, in: Carson, W., Schnitzer, S. (Eds.), Tropical Forest Community Ecology. John Wiley \& Sons.

Chazdon, R.L., 2008. Beyond Deforestation: Restoring Forests and Ecosystem Services on Degraded Lands. Science 320, 1458-1460. doi:10.1126/science.1155365

Connell, J.H., Slatyer, R.O., 1977. Mechanisms of succession in natural communities and their role in community stability and organization. Am. Nat. 111, 11191144. 
Cornelissen, J., Lavorel, S., Garnier, S., Díaz, S., Buchmann, N., Gurvich, D., Reich, P., Steege, ter H., Morgan, H., Heijden, van de M., Pausas, J., Poorter, H., 2003. A handbook of protocols for standardised and easy measurement of plant functional traits worldwide. Aust. J. Bot. 51, 335-380.

Cusack, D., Montagnini, F., 2004. The role of native species plantations in recovery of understory woody diversity in degraded pasturelands of Costa Rica. For. Ecol. Manag. 188, 1-15. doi:10.1016/S0378-1127(03)00302-5

Dawson, T.E., Mambelli, S., Plamboeck, A.H., Templer, P.H., Tu, K.P., 2002. Stable Isotopes in Plant Ecology. Annu. Rev. Ecol. Syst. 33, 507-559.

Dent, D.H., DeWalt, S.J., Denslow, J.S., 2013. Secondary forests of central Panama increase in similarity to old-growth forest over time in shade tolerance but not species composition. J. Veg. Sci. 24, 530-542. doi:10.1111/j.16541103.2012.01482.x

Donovan, L.A., Ehleringer, J.R., 1994. Water stress and use of summer precipitation in a Great Basin shrub community. Funct. Ecol. 8, 289-297. doi:10.2307/2389821

Fenner, M., Thompson, K., 2005. The ecology of seeds. Cambridge University Press.

Frazer, G.W., Canham, C.D., Lertzman, K.P., 1999. Gap Light Analyzer (GLA), Version 2.0: Imaging software to extract canopy structure and gap light transmission indices from true-colour fisheye photographs, users manual and program documentation. Simon Fraser University, Burnaby, British Columbia, and the Institute of Ecosystem Studies, Millbrook, New York.

Germishuizen, G., Meyer, N., others, 2003. Plants of southern Africa: an annotated checklist. National Botanical Institute Pretoria.

Gotelli, N., Graves, G., 1996. Null models in ecology. Smithsonian Institution Press, Washintong, DC. 
Gourlay, I.D., Smith, J.P., Barnes, R.D., 1996. Wood production in a natural stand of Acacia karroo in Zimbabwe. For. Ecol. Manag. 88, 289-295. doi:10.1016/S0378-1127(96)03782-6

Grainger, M.J., Aarde, R.J. van, 2012. Is Succession-based Management of Coastal Dune Forest Restoration Valid? Ecol. Restor. 30, 200-208. doi:10.3368/er.30.3.200

Grainger, M.J., van Aarde, R.J., 2013. The role of canopy gaps in the regeneration of coastal dune forest. Afr. J. Ecol. 51, 11-20. doi:10.1111/j.13652028.2012.01348.x

Hobbs, R.J., Higgs, E., Harris, J.A., 2009. Novel ecosystems: implications for conservation and restoration. Trends Ecol. Evol. 24, 599-605. doi:10.1016/j.tree.2009.05.012

Holl, K.D., Aide, T.M., 2011. When and where to actively restore ecosystems? For. Ecol. Manag. 261, 1558-1563.

Iida, Y., Kohyama, T.S., Swenson, N.G., Su, S.-H., Chen, C.-T., Chiang, J.-M., Sun, I.F., 2014. Linking functional traits and demographic rates in a subtropical tree community: the importance of size dependency. J. Ecol. 102, 641-650. doi:10.1111/1365-2745.12221

Isbell, F., Calcagno, V., Hector, A., Connolly, J., Harpole, W.S., Reich, P.B., SchererLorenzen, M., Schmid, B., Tilman, D., van Ruijven, J., Weigelt, A., Wilsey, B.J., Zavaleta, E.S., Loreau, M., 2011. High plant diversity is needed to maintain ecosystem services. Nature 477, 199-202. doi:10.1038/nature10282

Jennings, S. B., Brown, N. D., Sheil, D., 1999. Assessing forest canopies and understorey illumination: canopy closure, canopy cover and other measures. Forestry, 72(1), 59-74. 
Laliberté, E., Legendre, P., 2010. A distance-based framework for measuring functional diversity from multiple traits. Ecology 91, 299-305. doi:10.1890/08-2244.1

Lamb, D., 2014. Large-scale forest restoration. Routledge.

Lamb, D., Erskine, P.D., Parrotta, J.A., 2005. Restoration of degraded tropical forest landscapes. Science 310, 1628-1632. doi:10.1126/science.1111773

Lasky, J.R., Bachelot, B., Muscarella, R., Schwartz, N., Forero-Montaña, J., Nytch, C.J., Swenson, N.G., Thompson, J., Zimmerman, J.K., Uriarte, M., 2015. Ontogenetic shifts in trait-mediated mechanisms of plant community assembly. Ecology 96, 2157-2169. doi:10.1890/14-1809.1Lasky, J.R., Uriarte, M., Boukili, V.K., Chazdon, R.L., 2014a. Trait-mediated assembly processes predict successional changes in community diversity of tropical forests. Proc. Natl. Acad. Sci. U. S. A. 111, 5616-5621. doi:10.1073/pnas.1319342111

Lasky, J.R., Uriarte, M., Boukili, V.K., Erickson, D.L., Kress, W.J., Chazdon, R.L., 2014b. The relationship between tree biodiversity and biomass dynamics changes with tropical forest succession. Ecol. Lett. 17, 1158-1167. doi:10.1111/ele.12322

Laughlin, D.C., 2014. Applying trait-based models to achieve functional targets for theory-driven ecological restoration. Ecol. Lett. 17, 771-784. doi:10.1111/ele. 12288

Lawes, M., Midgley, J., Chapman, C., 2004. South Africa's forests. The ecology and sustainable use of indigenous timber resources. Indig. For. Woodl. South Afr. Policy People Pract. Univ. KwaZulu-Natal Press Pietermaritzbg. 31-75.

Lebrija-Trejos, E., Meave, J.A., Poorter, L., Pérez-García, E.A., Bongers, F., 2010a. Pathways, mechanisms and predictability of vegetation change during tropical 
dry forest succession. Perspect. Plant Ecol. Evol. Syst. 12, 267-275. doi:10.1016/j.ppees.2010.09.002

Lebrija-Trejos, E., Pérez-García, E.A., Meave, J.A., Bongers, F., Poorter, L., 2010b. Functional traits and environmental filtering drive community assembly in a species-rich tropical system. Ecology 91, 386-398. doi:10.1890/08-1449.1

Letts, M.G., Rodríguez-Calcerrada, J., Rolo, V., Rambal, S., 2012. Long-term physiological and morphological acclimation by the evergreen shrub Buxus sempervirens L. to understory and canopy gap light intensities. Trees 26,479 491. doi:10.1007/s00468-011-0609-z

Lohbeck, M., Poorter, L., Martínez-Ramos, M., Rodriguez-Velázquez, J., van Breugel, M., Bongers, F., 2014. Changing drivers of species dominance during tropical forest succession. Funct. Ecol. 28, 1052-1058. doi:10.1111/1365-2435.12240

McNamara, S., Tinh, D.V., Erskine, P.D., Lamb, D., Yates, D., Brown, S., 2006. Rehabilitating degraded forest land in central Vietnam with mixed native species plantings. For. Ecol. Manag., Improving Productivity in Mixed-Species Plantations 233, 358-365. doi:10.1016/j.foreco.2006.05.033

Meiners, S.J., Cadotte, M.W., Fridley, J.D., Pickett, S.T.A., Walker, L.R., 2015. Is successional research nearing its climax? New approaches for understanding dynamic communities. Funct. Ecol. 29, 154-164. doi:10.1111/1365-2435.12391

Mouillot, D., Graham, N.A.J., Villéger, S., Mason, N.W.H., Bellwood, D.R., 2013. A functional approach reveals community responses to disturbances. Trends Ecol. Evol. 28, 167-177. doi:10.1016/j.tree.2012.10.004

Mucina, L., Rutherford, M.C., 2006. The vegetation of South Africa, Lesotho and Swaziland. Strelitzia No19 viii + 807 pp. 
Nakagawa, S., Schielzeth, H., 2013. A general and simple method for obtaining R2 from generalized linear mixed-effects models. Methods Ecol. Evol. 4, 133-142. doi:10.1111/j.2041-210x.2012.00261.x

Nguyen, H., Firn, J., Lamb, D., Herbohn, J., 2014. Wood density: A tool to find complementary species for the design of mixed species plantations. For. Ecol. Manag. 334, 106-113. doi:10.1016/j.foreco.2014.08.022

Olivier, P.I., van Aarde, R.J., 2014. Multi-scale sampling boosts inferences from beta diversity patterns in coastal forests of South Africa. J. Biogeogr. 41, 1428-1439. doi:10.1111/jbi.12303

Pérez-Harguindeguy, N., Díaz, S., Garnier, E., Lavorel, S., Poorter, H., Jaureguiberry, P., Bret-Harte, M.S., Cornwell, W.K., Craine, J.M., Gurvich, D.E., Urcelay, C., Veneklaas, E.J., Reich, P.B., Poorter, L., Wright, I.J., Ray, P., Enrico, L., Pausas, J.G., de Vos, A.C., Buchmann, N., Funes, G., Quétier, F., Hodgson, J.G., Thompson, K., Morgan, H.D., ter Steege, H., van der Heijden, M.G.A., Sack, L., Blonder, B., Poschlod, P., Vaieretti, M.V., Conti, G., Staver, A.C., Aquino, S., Cornelissen, J.H.C., 2013. New handbook for standardised measurement of plant functional traits worldwide. Aust. J. Bot. 61, 167-234.

Pfeifer, M., Gonsamo, A., Disney, M., Pellikka, P., Marchant, R., 2012. Leaf area index for biomes of the Eastern Arc Mountains: Landsat and SPOT observations along precipitation and altitude gradients. Remote Sens. Environ. 118, 103-115. doi:10.1016/j.rse.2011.11.009

Podadera, D.S., Engel, V.L., Parrotta, J.A., Machado, D.L., Sato, L.M., Durigan, G., 2015. Influence of removal of a non-native tree species Mimosa caesalpiniifolia Benth. on the regenerating plant communities in a tropical semideciduous forest 
under restoration in Brazil. Environ. Manage. 56, 1148-1158.

doi:10.1007/s00267-015-0560-7

Poorter, L., 2001. Light-dependent changes in biomass allocation and their importance for growth of rain forest tree species. Funct. Ecol. 15, 113-123. doi:10.1046/j.1365-2435.2001.00503.x

Poorter, L., Bongers, F., 2006. Leaf traits are good predictors of plant performance across 53 rain forest species. Ecology 87, 1733-1743. doi:10.1890/00129658(2006)87[1733:LTAGPO]2.0.CO;2

Rodrigues, R.R., Lima, R.A.F., Gandolfi, S., Nave, A.G., 2009. On the restoration of high diversity forests: 30 years of experience in the Brazilian Atlantic Forest. Biol. Conserv., Conservation Issues in the Brazilian Atlantic Forest 142, 12421251. doi:10.1016/j.biocon.2008.12.008

Rolo, V., Olivier, P.I., Guldemond, R.A.R., van Aarde, R.J., 2016. Validating space-fortime substitution in a new-growth coastal dune forest. Appl. Veg. Sci. doi:10.1111/avsc.12210

Russo, S.E., Brown, P., Tan, S., Davies, S.J., 2008. Interspecific demographic trade-offs and soil-related habitat associations of tree species along resource gradients. J. Ecol. 96, 192-203. doi:10.1111/j.1365-2745.2007.01330.x

Schneider, C.A., Rasband, W.S., Eliceiri, K.W., 2012. NIH Image to ImageJ: 25 years of image analysis. Nat. Methods 9, 671-675. doi:10.1038/nmeth.2089

Spasojevic, M.J., Yablon, E.A., Oberle, B., Myers, J.A., 2014. Ontogenetic trait variation influences tree community assembly across environmental gradients. Ecosphere 5, 129. doi:10.1890/ES14-000159.1 
Suding, K.N., 2011. Toward an era of restoration in ecology: Successes, failures, and opportunities Ahead. Annu. Rev. Ecol. Evol. Syst. 42, 465-487. doi:10.1146/annurev-ecolsys-102710-145115

Swenson, N.G., 2014. Functional and Phylogenetic Ecology in R. Springer.

van Aarde, R., Guldemond, R.A.R., Olivier, P.I., 2014. Biodiversity status of coastal dune forest in South Africa, in: Maslo, B., Lockwood, J.L. (Eds.), Coastal Conservation. Cambridge University Press.

van Aarde, R.J., Coe, M., Niering, W., 1996. On the rehabilitation of the coastal dunes of KwaZulu-Natal. South Afr. J. Sci. 92, 122.

Vleut, I., Levy-Tacher, S.I., de Boer, W.F., Galindo-González, J., Ramírez-Marcial, N., 2013. Can a fast-growing early-successional tree (Ochroma pyramidale, Malvaceae) accelerate forest succession? J. Trop. Ecol. 29, 173-180. doi:10.1017/S0266467413000126

Wassenaar, T.D., van Aarde, R.J., Pimm, S.L., Ferreira, S.M., 2005. Community convergence in disturbed subtropical dune forest. Ecology 86, 655-666. doi:10.1890/03-0836

West, P.W., 2009. Stand Measurement, in: Tree and Forest Measurement. Springer Berlin Heidelberg, pp. 65-89.

Westoby, M., Falster, D.S., Moles, A.T., Vesk, P.A., Wright, I.J., 2002. Plant ecological strategies: Some leading dimensions of variation between species. Annu. Rev. Ecol. Syst. 33, 125-159.

Whitmore, T.C., 1989. Canopy gaps and the two major groups of forest trees. Ecology 70, 536. doi:10.2307/1940195 
Wright, I.J., Reich, P.B., Westoby, M., Ackerly, D.D., Baruch, Z., Bongers, F., Cavender-Bares, J., Chapin, T., Cornelissen, J.H., Diemer, M., others, 2004. The worldwide leaf economics spectrum. Nature 428, 821-827.

Wright, S.J., Kitajima, K., Kraft, N.J.B., Reich, P.B., Wright, I.J., Bunker, D.E., Condit, R., Dalling, J.W., Davies, S.J., Díaz, S., Engelbrecht, B.M.J., Harms, K.E., Hubbell, S.P., Marks, C.O., Ruiz-Jaen, M.C., Salvador, C.M., Zanne, A.E., 2010. Functional traits and the growth-mortality trade-off in tropical trees. Ecology 91, 3664-3674. doi:10.1890/09-2335.1 
Appendices.

Table A1. Number of individuals sampled, Standard Error per trait (SLA: specific leaf area; WD: wood density; $\delta^{13} \mathrm{C}$ composition) and the site of each species where an individual was sampled (O: old-growth; L: late; I: intermediate; Y: young).

\begin{tabular}{|c|c|c|c|c|c|}
\hline Species & N. Individual & SLA & WD & $\delta^{13} \mathrm{C}$ & Occurrence \\
\hline Acacia karroo & 43 & 5.20 & 0.004 & 0.15 & ALL \\
\hline Albizia adianthifolia & 3 & 29.36 & 0.022 & 1.58 & $\mathrm{O}, \mathrm{L}, \mathrm{I}$ \\
\hline Allophylus natalensis & 18 & 7.88 & 0.006 & 0.40 & $\mathrm{O}, \mathrm{L}, \mathrm{I}$ \\
\hline Antidesma venosum & 1 & & & & I \\
\hline Apodytes dimidiata & 8 & 8.03 & 0.011 & 0.32 & ALL \\
\hline Bauhinia tomentosa & 1 & & & & $\mathrm{~L}$ \\
\hline Brachylaena discolor & 13 & 5.41 & 0.007 & 0.26 & L, I, Y \\
\hline Bridelia cathartica & 1 & & & & $\mathrm{Y}$ \\
\hline Bridelia micrantha & 1 & & & & I \\
\hline Canthium inerme & 20 & 8.21 & 0.009 & 0.27 & $\mathrm{O}, \mathrm{L}, \mathrm{I}$ \\
\hline Carissa bispinosa & 3 & 12.56 & 0.027 & 0.91 & $\mathrm{O}, \mathrm{L}$ \\
\hline Carissa macrocarpa & 1 & & & & $\mathrm{~L}$ \\
\hline Catunaregam obovata & 1 & & & & $\mathrm{O}$ \\
\hline Celtis africana & 33 & 11.34 & 0.005 & 0.23 & ALL \\
\hline Chaetachme aristata & 6 & 10.54 & 0.009 & 0.68 & $\mathrm{O}, \mathrm{I}, \mathrm{Y}$ \\
\hline Chionanthus peglerae & 4 & 11.99 & 0.017 & 0.97 & $\mathrm{O}$ \\
\hline Clausena anisata & 3 & 12.89 & 0.011 & 0.20 & $\mathrm{O}$ \\
\hline Clerodendrum glabrum & 11 & 9.15 & 0.013 & 0.39 & ALL \\
\hline Cordia caffra & 4 & 12.00 & 0.028 & 0.33 & $\mathrm{O}, \mathrm{L}$ \\
\hline Cussonia sphaerocephala & 1 & & & & $\mathrm{Y}$ \\
\hline Deinbollia oblongifolia & 8 & 10.99 & 0.009 & 0.40 & $\mathrm{O}, \mathrm{I}$ \\
\hline Diospyros natalensis & 5 & 2.70 & 0.009 & 0.32 & $\mathrm{O}$ \\
\hline Dovyalis longispina & 8 & 8.12 & 0.009 & 0.70 & $\mathrm{O}, \mathrm{Y}$ \\
\hline Drypetes natalensis & 5 & 5.37 & 0.020 & 0.32 & $\mathrm{O}$ \\
\hline Ekebergia capensis & 3 & 15.98 & 0.005 & 1.62 & $\mathrm{~L}$ \\
\hline Englerophytum natalense & 2 & 11.43 & 0.004 & 0.53 & $\mathrm{O}$ \\
\hline Erythrococca berberidea & 4 & 29.88 & 0.033 & 0.47 & $\mathrm{O}$ \\
\hline Erythroxylum emarginatum & 2 & 2.80 & 0.007 & 1.18 & $\mathrm{O}$ \\
\hline Euclea natalensis & 2 & 20.44 & 0.005 & 0.87 & $\mathrm{O}$ \\
\hline Ficus lutea & 1 & & & & $\mathrm{O}$ \\
\hline Ficus sur & 1 & & & & I \\
\hline Grewia occidentalis & 8 & 13.52 & 0.008 & 0.35 & L, I, Y \\
\hline Gymnosporia arenicola & 9 & 8.24 & 0.011 & 0.42 & $\mathrm{O}, \mathrm{L}, \mathrm{Y}$ \\
\hline Harpephyllum caffrum & 1 & & & & $\mathrm{~L}$ \\
\hline Kraussia floribunda & 3 & 7.49 & 0.013 & 0.60 & $\mathrm{~L}, \mathrm{I}$ \\
\hline Maytenus procumbens & 1 & & & & $\mathrm{~L}$ \\
\hline Mimusops caffra & 8 & 7.32 & 0.005 & 0.59 & $\mathrm{O}, \mathrm{L}, \mathrm{I}$ \\
\hline Ochna natalitia & 4 & 12.93 & 0.003 & 0.38 & $\mathrm{O}$ \\
\hline Olea woodiana & 8 & 9.03 & 0.007 & 0.55 & $\mathrm{O}, \mathrm{Y}$ \\
\hline Pavetta revoluta & 3 & 20.30 & 0.020 & 0.56 & $\mathrm{O}$ \\
\hline Peddiea africana & 2 & 22.17 & 0.002 & 0.23 & $\mathrm{~L}$ \\
\hline Psychotria capensis & 9 & 15.89 & 0.019 & 0.49 & $\mathrm{O}, \mathrm{Y}$ \\
\hline Psydrax obovata & 3 & 7.55 & 0.007 & 0.62 & $\mathrm{O}, \mathrm{L}, \mathrm{Y}$ \\
\hline
\end{tabular}


Continue from previous page

\begin{tabular}{|l|r|r|r|r|l|}
\hline Scolopia zeyheri & 2 & 9.25 & 0.023 & 0.99 & $\mathrm{O}$ \\
\hline Searsia natalensis & 3 & 8.80 & 0.004 & 0.91 & $\mathrm{~L}$ \\
\hline Sideroxylon inerme & 15 & 7.64 & 0.012 & 0.39 & $\mathrm{O}, \mathrm{L}, \mathrm{Y}$ \\
\hline Strychnos gerrardii & 6 & 14.31 & 0.007 & 0.38 & $\mathrm{O}$ \\
\hline Teclea gerrardii & 15 & 10.56 & 0.009 & 0.34 & $\mathrm{O}, \mathrm{Y}$ \\
\hline Trema orientalis & 1 & & & & $\mathrm{I}$ \\
\hline Trichilia emetica & 5 & 12.87 & 0.004 & 0.64 & $\mathrm{~L}$ \\
\hline Tricalysia sonderiana & 5 & 6.77 & 0.010 & 0.52 & $\mathrm{O}, \mathrm{L}, \mathrm{I}$ \\
\hline Turraea floribunda & 7 & 18.17 & 0.008 & 0.55 & $\mathrm{O}, \mathrm{L}, \mathrm{Y}$ \\
\hline Vangueria randii & 2 & 29.07 & 0.039 & 0.80 & $\mathrm{O}$ \\
\hline Vepris lanceolata & 9 & 5.24 & 0.004 & 0.46 & $\mathrm{~L}, \mathrm{I}, \mathrm{Y}$ \\
\hline Zanthoxylum capense & 1 & & & & $\mathrm{~L}$ \\
\hline
\end{tabular}


Figure A1 Monthly average rainfall $(\mathrm{mm})$ and temperature $\left({ }^{\circ} \mathrm{C}\right)$ of the studied sites.

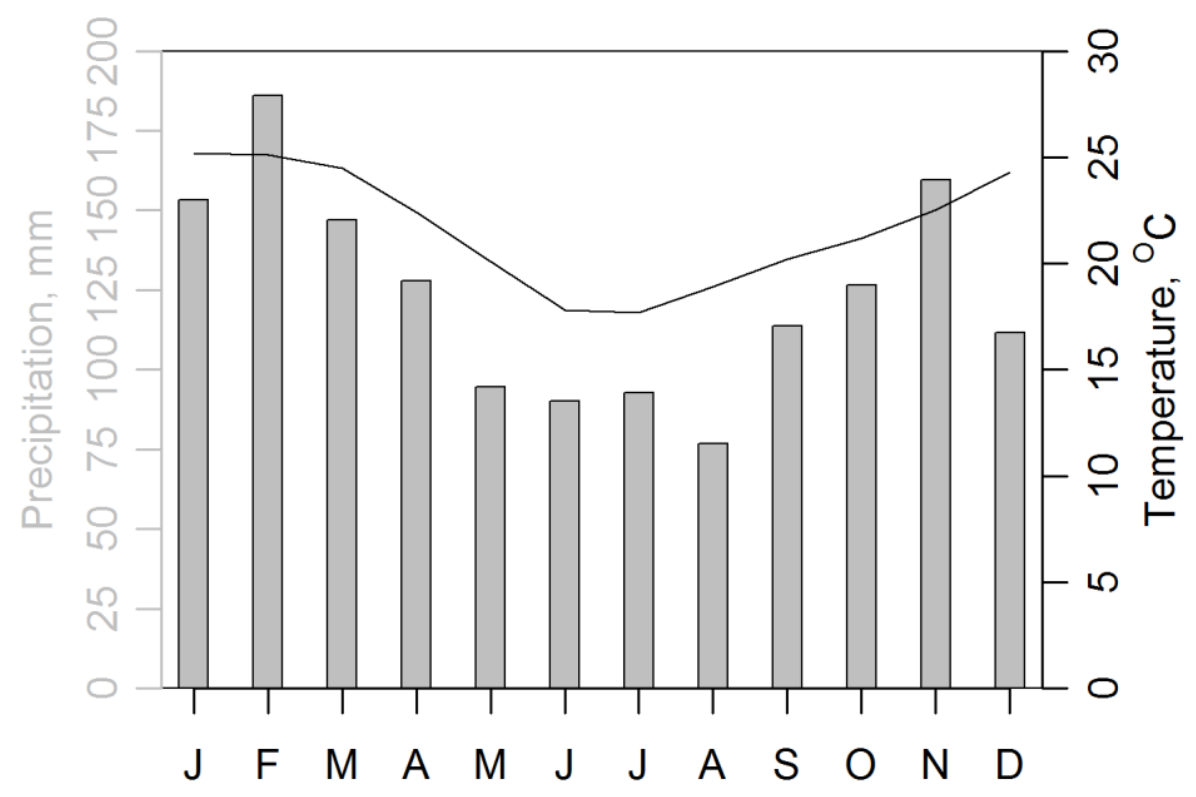


Figure A2. Principal components analysis of environmental variables (elevation, slope and aspect) of each sampling point. Both axis explain $75.8 \%$ of the variance. The first component is negatively related to elevation and aspect and the second component is positively related to slope.

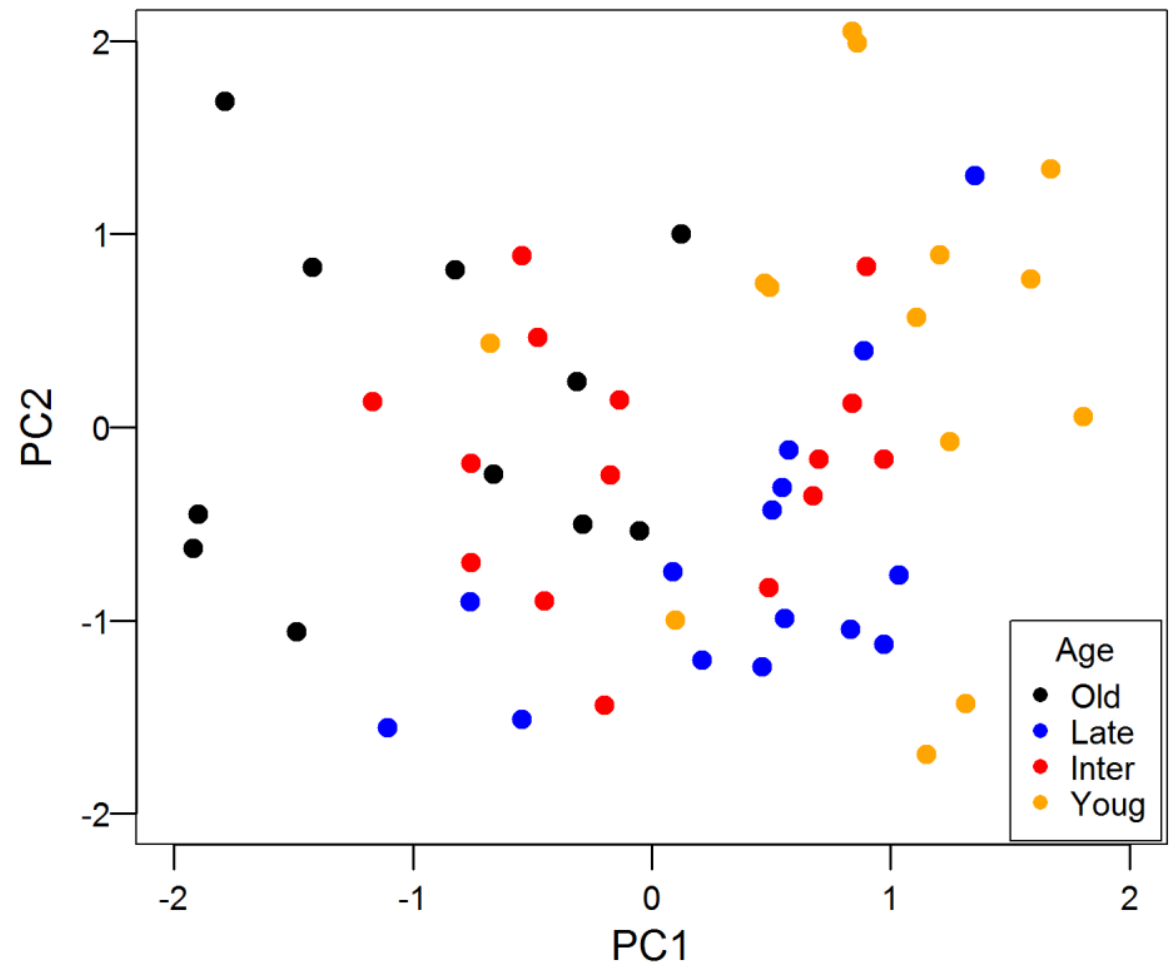

